\title{
Range and primary habitats of Hawaiian insular false killer whales: informing determination of critical habitat
}

\author{
Robin W. Baird ${ }^{1, *}$, M. Bradley Hanson ${ }^{2}$, Gregory S. Schorr ${ }^{1}$, Daniel L. Webster ${ }^{1}$, \\ Daniel J. McSweeney ${ }^{3}$, Antoinette M. Gorgone ${ }^{4}$, Sabre D. Mahaffy ${ }^{1}$, Damon M. \\ Holzer $^{2}$, Erin M. Oleson ${ }^{5}$, Russel D. Andrews ${ }^{6}$ \\ ${ }^{1}$ Cascadia Research Collective, 218 1/2 W. 4th Avenue, Olympia, Washington 98501, USA \\ ${ }^{2}$ NOAA Northwest Fisheries Science Center, 2725 Montlake Blvd. E., Seattle, Washington 98112, USA \\ ${ }^{3}$ Wild Whale Research Foundation, Box 139, Holualoa, Hawai'i 96725, USA \\ ${ }^{4}$ NOAA Southeast Fisheries Science Center, 101 Pivers Island Road, Beaufort, North Carolina 98250, USA \\ ${ }^{5}$ NOAA Pacific Islands Fisheries Science Center, 1601 Kapiolani Blvd., Honolulu, Hawai'i 96814, USA \\ ${ }^{6}$ School of Fisheries and Ocean Sciences, University of Alaska Fairbanks, and Alaska SeaLife Center, 301 Railway Ave., \\ Seward, Alaska 99664, USA
}

\begin{abstract}
For species listed under the US Endangered Species Act, federal agencies must designate 'critical habitat', areas containing features essential to conservation and/or that may require special management considerations. In November 2010, the National Marine Fisheries Service proposed listing a small demographically isolated population of false killer whales Pseudorca crassidens in Hawai'i as endangered but has not yet proposed designating critical habitat. We assessed the population's range and heavily used habitat areas using data from 27 satellite tag deployments. Assessment of independence of individuals with temporally overlapping data indicated that data were from 22 'groups'. Further analyses were restricted to 1 individual per group. Tag data were available for periods of between 13 and $105 \mathrm{~d}$ (median $=40.5 \mathrm{~d}$ ), with 8513 locations (93.4\% from July-January). Analyses of photo-identification data indicated that the population is divided into 3 large associations of individuals (social clusters), with tag data from 2 of these clusters. Ranges for these 2 clusters were similar, although one used significantly deeper waters, and their high-use areas differed. A minimum convex polygon range encompassing all locations was $~ 82800 \mathrm{~km}^{2}$, with individuals ranging from Ni'ihau to Hawai'i Island and up to $122 \mathrm{~km}$ offshore. Three high-use areas were identified: (1) off the north half of Hawai'i Island, (2) north of Maui and Moloka'i and (3) southwest of Lana'i. Although this analysis provides information useful for decision-making concerning designation of critical habitat, there are likely other high-use areas that have not yet been identified due to seasonal limitations and availability of data from only 2 of the 3 main social clusters.
\end{abstract}

KEY WORDS: Critical habitat $\cdot$ Range $\cdot$ Habitat use $\cdot$ Satellite tagging

\section{INTRODUCTION}

False killer whales Pseudorca crassidens are generally considered a wide-ranging open-ocean species inhabiting tropical and warm-temperate waters.
Although false killer whales have been observed close to land, including reports of repeated sightings of specific individuals near oceanic islands (e.g. Acevedo-Gutiérrez et al. 1997), the only population of false killer whales known to restrict their move- 
ments to the vicinity of an oceanic island group occurs in the Hawaiian Archipelago (Baird et al. 2008, 2010). The Hawaiian insular false killer whale population exhibits a very cohesive social structure, with all identified individuals within the population associated and regularly interacting with at least one, and often several, common individuals (Baird 2009). This genetically distinct population is characterized by nearly unique mitochondrial DNA haplotypes and experiences low levels of male-mediated gene flow with pelagic populations (Chivers et al. 2007, 2010). This level of genetic differentiation is suggestive of local adaptation, which, together with island-associated movement patterns and occurrence in shallow near-island habitats with elevated localized productivity, may indicate adaptation to a local habitat different than that of their oceanic conspecifics, even when foraging on similar prey species. These population characteristics contributed to the determination of this population as a distinct population segment (DPS) under the US Endangered Species Act (ESA) (Oleson et al. 2010).

In November 2010, the National Marine Fisheries Service (NMFS) proposed to list the Hawaiian insular false killer whale DPS as endangered under the ESA (Federal Register 2010). For a species or DPS listed under the ESA, the Act requires federal agencies to designate 'critical habitat'. Critical habitat may include 'specific areas outside of the geographical area occupied by the species or DPS at the time of listing' 'upon a determination by the Secretary [of Commerce] that such areas are essential for the conservation of the species [or DPS]', as well as 'specific areas within the geographical area occupied by the species at the time of listing, if they contain those physical or biological features essential to the conservation of the species [or DPS], and which may require special management considerations or protection' (16 U.S.C. 1532(5)(A)(i), (ii)). Although decisions on which areas to designate may take into account national security concerns as well as the economic impacts of such listings, Section $4(\mathrm{~b})(2)$ of the ESA requires such designation to be based on the 'best scientific data available'. Critical habitat listings should include physical or biological features, known as primary constituent elements (PCEs), such as feeding areas, sites for reproduction, and habitats that are protected from disturbance. At the time of the proposed listing, no proposal to designate critical habitat was made; however, information to inform such a designation was requested (Federal Register 2010).

Since 2000 we have been studying false killer whales in Hawaiian waters and have compiled infor- mation on sightings and movements of photo-identified individuals among islands (Baird et al. 2008). Given the small population size (estimated at approximately 150 individuals), their wide-ranging movements, and the restrictions of working offshore or on the windward sides of the islands, accumulation of information on the range of the population and habitats used was both slow and biased. In 2007, we began remotely deploying satellite tags on individuals from the Hawaiian insular population to examine movements and habitat use (Baird et al. 2010). Such tracks from tagged individuals greatly increased what was known about the offshore and windward range of the population and the rate and extent of movements among islands, and also provided documentation that individuals from the central and eastern main Hawaiian Islands use the area around Kaua'i and Ni'ihau (Baird et al. 2010, 2011a) (see Fig. 3 for location of islands). Although information from satellite tag data available through early 2010 was incorporated into the NMFS status assessment (Oleson et al. 2010), no particular attempt has been made to identify specific geographic regions or habitat features that may be important to this population. Since the NMFS status assessment, additional data have been obtained from several individuals that were satellite tagged in October and December 2010. In the present study we combine data from all satellite tags deployed on Hawaiian insular false killer whales through the end of 2010 to assess which areas within their range are used most frequently and thus contribute information for consideration in critical habitat designation. We explore several ways of identifying high-use areas within the range of the population, try to minimize pseudoreplication by identifying cases where location data are available for multiple individuals that are not acting independently, and assess the limitations of our sample for describing both the range of the population and high-density areas within it. We also assess knowledge of feeding areas and locations where calves have been documented.

\section{MATERIALS AND METHODS}

The tagging methods used were previously described by Baird et al. (2010). The tags used were based on a design of Andrews et al. (2008) which has been used on 18 species of cetaceans (e.g. Schorr et al. 2009, Baird et al. 2011b, Woodworth et al. 2011). The tag contained either a Wildlife Computers' ARGOS-linked SPOT5 location-only (23 tags) or Mk10-A 
dive depth transmitting (4 tags) Platform Transmitter Terminal in the Low-Impact Minimally-Percutaneous External-electronics Transmitter (LIMPET) configuration. The LIMPET tag attaches to the dorsal fin or the base of the dorsal fin with two 6.5 - $\mathrm{cm}$ penetrating titanium darts with backward-facing petals. Dimensions of the SPOT5 LIMPET tags (without darts) were $63 \times$ $30 \times 21 \mathrm{~mm}$, and the total mass of the entire tag package was approximately $49 \mathrm{~g}$. Dimensions of the Mk10-A LIMPET tags (without darts) were $52 \times 53 \times$ $24 \mathrm{~mm}$, and the total mass of the entire tag package was approximately $59 \mathrm{~g}$. Tags were duty cycled in several different ways, primarily depending on the year they were deployed, and in 2010 whether they were SPOT5 or Mk10-A tags (see 'Results'). Tags were remotely deployed on false killer whales using a Dan-Inject JM Special 25 pneumatic projector.

Fieldwork for tagging was undertaken off the island of Hawai'i from 2007 to 2010, and off the island of O'ahu in 2009 and 2010. We targeted individual whales for tagging depending on the clustering of individuals and their behavior. Although groups encountered were of mixed age and sex, larger individuals that were separated by tens of meters from other whales were preferentially chosen to increase the likelihood of optimum tag location (mid-dorsal fin) and minimize potential harassment of other individuals present in the group. Whales with neonates or small calves present in close proximity were not targeted for tagging. When tags were deployed on multiple individuals within a larger aggregation, attempts were made to deploy tags on individuals in different subgroups (e.g. groups separated by at least 300 to $400 \mathrm{~m}$ ) to maximize the likelihood of tagged individuals acting independently. Immediate reactions of tagged whales and companion individuals to tagging were noted. Tagged and companion whales were photographed to identify individuals.

Photographs of tagged and companion individuals were compared with photographs in an existing photo-identification catalog that includes individuals from both the insular population and the offshore population, following the protocols described by Baird et al. (2008). Age class (adult, subadult) of tagged whales was estimated based on body size relative to other individuals, both in the field and in photographs, as well as by sighting history for some individuals. Sex of tagged individuals was based on genetic analyses of biopsy samples collected either during the encounter or in a prior or subsequent encounter (see Chivers et al. 2007, 2010), or determined using information from the entire sighting history (i.e. sightings before or after the individual was tagged). Observations of the individual with a neonate or small calf in close proximity at some point during the individual's sighting history suggested the whale was an adult female. If an individual had been documented for more than $10 \mathrm{yr}$ and had not been documented with a neonate or small calf present, and had not been previously biopsied, it was considered a possible male (designated ' $\mathrm{M}$ ?' in Table 1). Each individual was designated by an alphanumeric catalog number (HIPc\#\#\#) after Baird et al. (2008).

Tagged whale locations were estimated by the Argos System (Collecte Localisation Satellites) using the least-squares method and were assessed for plausibility using the Douglas Argos-Filter v. 7.08 (available at http://alaska.usgs.gov/science/biology/spatial/ douglas.html). This filter includes a number of userdefined variables: maximum redundant distance (consecutive points separated by less than a defined distance are kept by the filter because Argos location errors rarely occur in the same place, so very close temporally consecutive points are assumed to be selfconfirming); location classes (LCs) that are automatically retained; maximum sustainable rate of movement; and the rate coefficient (Ratecoef) for assessing the angle created by 3 consecutive points. The rate coefficient algorithm takes into account that the farther an animal moves between locations, the less likely it is to return to or near to the original location without any intervening positions, creating an acute angle characteristic of typical Argos error. We automatically retained locations separated from the next location by less than a maximum redundant distance of $3 \mathrm{~km}$, as well as LC2 and LC3 locations (estimated error of $<500$ and $<250 \mathrm{~m}$, respectively; Argos User's Manual). LC1 locations (with estimated error of between 500 and $1500 \mathrm{~m}$ ), as well as LC0, LCA, LCB, and LCZ locations (with no estimation of accuracy), were only retained if they passed the Douglas ArgosFilter process. For maximum sustainable rate of movement, we used $20 \mathrm{~km} \mathrm{~h}^{-1}$, based on maximum travel speeds noted during observations of fasttraveling false killer whales in Hawai'i (R. W. Baird pers. obs.). We used the default Ratecoef for marine mammals (Ratecoef $=25$ ).

Given the strong social relationships evidenced by photo-identification data (Baird et al. 2008), we assessed whether tagged individuals might not be acting independently, and thus whether pseudoreplication was an issue. The straight-line distance (i.e. not taking into account potentially intervening land masses) between pairs of individuals was calculated when locations were obtained during a single satellite overpass ( 10 $\mathrm{min})$. We used both the average dis- 
Table 1. Pseudorca crassidens. Details of satellite-tagged Hawaiian insular false killer whales used in this study. A: adult; SA: subadult; M: male; $(\mathrm{g})$ : sex based on genetic analysis; M?: no neonates or calves observed for an individual with an extended sighting history; Unk: unknown (i.e. short sighting history, no calves or neonates observed, no genetic analysis); F: female; (n): neonate in close proximity; (ca): calf in close proximity

\begin{tabular}{|c|c|c|c|c|c|c|c|c|}
\hline Tag ID & $\begin{array}{l}\text { Individual } \\
\text { ID }\end{array}$ & $\begin{array}{l}\text { Age } \\
\text { class }\end{array}$ & Sex & Island & $\begin{array}{l}\text { Date } \\
\text { tagged }\end{array}$ & $\begin{array}{l}\text { Tag } \\
\text { type }\end{array}$ & Tag duty cycling & $\begin{array}{l}\text { No. hours } \\
\text { ansm. per day }\end{array}$ \\
\hline Pc Tag 1 & HIPc217 & $\mathrm{A}$ & $M(g)$ & Hawai'i & 15-Aug-07 & SPOT5 & Daily & 8 \\
\hline Pc Tag 2 & HIPc276 & A & Unk & Hawai'i & 15-Aug-07 & SPOT5 & Daily & 8 \\
\hline Pc Tag 3 & HIPc107 & A & M? & Hawai'i & 15-Aug-07 & SPOT5 & Daily & 8 \\
\hline Pc Tag 5 & HIPc272 & SA & Unk & Hawai'i & $16-J u l-08^{\mathrm{a}}$ & SPOT5 & Daily & 13 \\
\hline Pc Tag 6 & HIPc179 & $\mathrm{A}$ & $M(g)$ & Hawai'i & 16-Jul-08 & SPOT5 & Daily & 13 \\
\hline Pc Tag 7 & HIPc202 & $\mathrm{A}$ & Unk & Hawai'i & 16-Jul-08 & SPOT5 & Daily & 13 \\
\hline Pc Tag 8 & HIPc145 & $\mathrm{A}$ & $\mathrm{F}(\mathrm{n})$ & Hawai'i & 16-Jul-08 & SPOT5 & Daily & 13 \\
\hline Pc Tag 9 & HIPc205 & $\mathrm{A}$ & $\mathrm{M}(\mathrm{g})$ & Hawai'i & 16-Jul-08 & SPOT5 & Daily & 13 \\
\hline Pc Tag 10 & HIPc209 & $\mathrm{A}$ & Unk & Hawai'i & 26-Jul-08 & SPOT5 & Daily & 13 \\
\hline Pc Tag 11 & HIPc213 & $\mathrm{A}$ & $\mathrm{M}$ ? & Hawai'i & 26-Jul-08 & SPOT5 & Daily & 13 \\
\hline Pc Tag 12 & HIPc172 & $\mathrm{A}$ & $M(g)$ & Hawai'i & 10-Dec-08 & SPOT5 & Daily & 13 \\
\hline Pc Tag 13 & HIPc314 & SA & Unk & O’ahu & 05-Oct-09 & SPOT5 & Daily for $60 \mathrm{~d}$, then every 2 nd $d$ & 8 \\
\hline Pc Tag 14 & HIPc357 & A & $\mathrm{F}(\mathrm{ca})$ & O’ahu & 13-Oct-09 & SPOT5 & Daily & 9 \\
\hline Pc Tag 15 & HIPc358 & A & $\mathrm{F}(\mathrm{ca})$ & O'ahu & 14-Oct-09 & SPOT5 & $\begin{array}{c}\text { Daily for } 60 \mathrm{~d} \text {, every } 2 \text { nd d to Day } 90 \text {, } \\
\text { then every } 5 \text { th } d\end{array}$ & 0, \\
\hline Pc Tag 16 & HIPc317 & $\mathrm{A}$ & Unk & O’ahu & 16-Oct-09 & SPOT5 & Daily & 9 \\
\hline Pc Tag 17 & HIPc145 & $\mathrm{A}$ & $\mathrm{F}(\mathrm{n})$ & O’ahu & 17-Oct-09 & SPOT5 & $\begin{array}{c}\text { Daily for } 50 \mathrm{~d} \text {, every } 2 \text { nd d to Day } 66, \\
\text { then every } 3 \mathrm{rd} \mathrm{d}\end{array}$ & 6, \\
\hline Pc Tag 20 & HIPc347 & A & Unk & Hawai'i & 10-Dec-09 & SPOT5 & $\begin{array}{c}\text { Daily for } 60 \mathrm{~d} \text {, every } 2 \text { nd } d \text { to Day } 90 \text {, } \\
\text { then every } 5 \text { th } d\end{array}$ & 0, \\
\hline Pc Tag 21 & HIPc365 & $\mathrm{A}$ & $\mathrm{F}(\mathrm{g})$ & Hawai'i & 10-Dec-09 & SPOT5 & Daily & 9 \\
\hline Pc Tag 22 & HIPc351 & SA & $\mathrm{F}(\mathrm{g})$ & Hawai'i & 18-Dec-09 & SPOT5 & $\begin{array}{c}\text { Daily for } 60 \mathrm{~d} \text {, every } 2 \text { nd d to Day } 90, \\
\text { then every } 5 \text { th } d\end{array}$ & 0, \\
\hline Pc Tag 23 & HIPc115 & A & $M(g)$ & Hawai'i & 18-Dec-09 & SPOT5 & Daily & 9 \\
\hline Pc Tag 26 & HIPc200 & $\mathrm{A}$ & $\mathrm{M}(\mathrm{g})$ & O’ahu & 15 -Oct-10 & Mk10-A & Daily & 16 \\
\hline Pc Tag 27 & HIPc132 & $\mathrm{A}$ & $M(g)$ & O’ahu & 22-Oct-10 & SPOT5 & Daily & 9 \\
\hline Pc Tag 28 & HIPc272 & $\mathrm{A}$ & Unk & O’ahu & 22-Oct-10 & Mk10-A & $\begin{array}{c}\text { Daily for } 25 \mathrm{~d} \text {, every } 2 \text { nd d to Day } 33 \text {, } \\
\text { then every } 8 \text { th } d\end{array}$ & 3, \\
\hline Pc Tag 29 & HIPc173 & A & $F(g)$ & Hawai`i & 11-Dec-10 & SPOT5 & Daily & 9 \\
\hline Pc Tag 30 & HIPc302 & $\mathrm{A}$ & Unk & Hawai'i & 11-Dec-10 & Mk10-A & $\begin{array}{c}\text { Daily for } 24 \mathrm{~d} \text {, every } 2 \text { nd d to Day } 32 \text {, } \\
\text { every 8th d }\end{array}$ & 2, \\
\hline Pc Tag 31 & HIPc204 & $\mathrm{A}$ & $M(g)$ & Hawai'i & 11-Dec-10 & SPOT5 & Daily & 9 \\
\hline Pc Tag 32 & HIPc169 & $\mathrm{A}$ & $M(g)$ & Hawai'i & 11-Dec-10 & Mk10-A & Daily for $24 \mathrm{~d}$, then every 2 nd d & 15 \\
\hline
\end{tabular}

tances between pairs of individuals and the maximum distance between pairs to assess whether individuals were acting independently. Individuals were considered to be acting in concert if the average distance between a pair of individuals was less than $5 \mathrm{~km}$ and the maximum distance between a pair was less than $25 \mathrm{~km}$ over the period with overlapping data (see 'Results'). For analyses of high-use areas, when a pair or trio of individuals were considered to be acting in concert, the track(s) of the animal(s) with the shortest duration was excluded from further analyses. In 1 case, 2 individuals were determined to be travelling in association based on average and maximum distances, but during part of the period of overlap the tags were duty cycled to transmit on alternate days. In this case, the data from alternate days from the 2 individuals during this period of alternating transmissions were combined to produce a single track.

Maps used to assess high-usage areas were produced in ArcGIS v. 9.2 (ESRI) using the reduced data set (i.e. using only one of each pair or trio of individuals acting in concert). All data were summarized using a vector grid composed of $5 \times 5 \mathrm{~km}$ cells that encompassed the range of all the tracking locations. We chose grid cells of $5 \times 5 \mathrm{~km}$, large enough to account for error in Argos locations and to accommodate the typical wide spatial spread of false killer whale groups (Baird et al. 2008). A spatial join was used to associate locations within grid cells. Additionally, track lines were developed by connecting the locations in temporal sequence and intersecting the resulting features by the overlay grid. 
Four different density maps were created using different classification attributes within the gridded data set, with each cell classified based on: (1) number of records, (2) total visit duration, (3) total visit duration with a late start (defined below) and (4) number of unique tags. Each method has specific limitations. The number of records may be biased because all points are not equal, i.e. they represent highly variable amounts of time, such that even if 2 adjacent cells contained the same number of data points, the amount of time actually spent in each cell could be different. In addition, given the time interval between consecutive locations as a result of duty cycling, the number of records method produces more gaps in cells around the periphery of the population's range (e.g. because of temporal gaps in transmissions, when tagged animals were farthest offshore there were gaps in cells in which no whales were documented, even though intervening cells had to be transited through). This method is most likely to be influenced by differences in duty cycling and, therefore, the number of locations per day among tags.

The other 3 methods of determining density values all used the linear tracks. For total visit duration, the time interval between locations was proportionately assigned to cells based on the percentage of the total length between sequential points contained within each grid cell. This assumes that individuals move at a constant speed and in a straight line between locations, which may be more plausible for short intervals than long intervals. This approach may also be biased towards areas near where individuals are first tagged if their movements after tagging are influenced by the location where they were tagged. To try to reduce or eliminate this bias, we also calculated total visit duration but with a 'late start', i.e. excluding data from the start of each track for a variable period of time. We chose to exclude the amount of time it would take for a tagged individual to travel from where it was tagged to the farthest point of the population's known range, assuming that this time interval would be sufficient to minimize bias because of the tagging site location. We first generated a minimum convex polygon surrounding all locations of all individuals. For each individual, the distance from the first location after tagging to the farthest vertex of the minimum convex polygon was calculated, as was the average speed of travel over the duration of the track. Using the average speed for each individual and the distance to the farthest point in the minimum convex polygon, the amount of time to travel to the farthest vertex was determined. For the 'late start' option, all locations for this time period were excluded; only locations after this time period were used in density maps. The number of unique tags simply tallies the number of tagged whales that were documented within particular grid cells, using the linear tracks. This approach does not include a time component and thus may under-represent preferences for particular areas as it would not identify areas which were reoccupied repeatedly, compared with areas where individuals rarely returned. The number of unique tags method will also over-represent areas where individuals are tagged if those areas happen to be used more for travel than for foraging. Given the varying range in values depending on the method used, values for all were normalized as the number of standard deviations above or below the mean value over all populated grid cells (i.e. grids cells with at least 1 occurrence of a tagged whale). We chose to classify cells with values that were $\geq 2$ SD above the mean value as 'high-density areas'.

To determine the known geographic range of the population, all locations (that passed the filter) from all individuals were utilized. The size of the known geographic range was determined by calculating the area within a minimum convex polygon surrounding all locations (excluding land masses) using ArcGIS v. 9.2. To assess potential habitat differences between high- and low-density areas, a number of environmental variables were calculated using ArcGIS v. 9.2, corresponding to the centroid for each grid cell where tagged whales were documented or where their paths intersected. These included depth, slope, and distance to shore, as well as whether locations were on the windward (north and east) or leeward (west) sides of the islands, following the methods of, and using the same bathymetry data as, Baird et al. (2010). We also summarized ocean color data (chlorophyll a [chl a] concentration) within grid cells using NOAA's Environmental Data Connector (EDC; available at www.pfeg.noaa.gov/products/edc/). Because $\mathrm{chl} a$ is the predominant form of chlorophyll in phytoplankton, the measurement of its distribution and concentration can be used as one index of marine productivity. The EDC tool provides a query-based link to a wide array of remotely sensed ocean satellite data. We used the Aqua Moderate Resolution Imagining Spectroradiometer (MODIS) data within EDC to summarize chl a concentrations. Chl a concentrations are calculated by the remote sensing of water-leaving radiances from NASA's Aqua Spacecraft and are distributed by NOAA CoastWatch. Chl a concentration (expressed as $\mathrm{mg} \mathrm{m}^{-3}$ ) was determined for 11 different months within our range of tracking data corresponding to those months with the greatest pro- 
portion of satellite data (e.g. December 2008, November 2009, December 2009). Mean concentrations for each month for each grid cell were queried from the Aqua MODIS data and averaged over the 11 months to compare high- and low-density cells.

To assess how representative tag data from an individual may be of the typical spatial use of that individual, in the 2 cases when an individual was tagged on multiple occasions, we mapped locations from each of the observation periods for comparison. To assess how representative our sample of tagged whales is of the population as a whole, and to determine whether there are differences in habitat use based on social groupings, photo-identification data from March 2000 through August 2011 were used to construct a social network, and tagged individuals were visually identified within the social network. A social network diagram was produced with Netdraw 2.097 (Analytic Technologies), with a spring embedding layout. We confirmed the existence of social groupings and membership within groups (termed social cluster or simply cluster in the following) with an analysis of network modularity (Q) in SOCPROG 2.4, which 'indicates how well a population can be delineated into communities or social units' (Whitehead 2008 , p. 146). When $\mathrm{Q}$ is greater than or equal to 0.3 , the population can be considered to be subdivided into clusters based on a clustering algorithm designed to maximize modularity using association indices (Newman 2004, 2006). Analyses were undertaken using the complete photo-identification data set from 2000-2010 and data from an almost 5-yr period (January 2007-August 2011) with the largest number of identifications, to minimize the influence of deaths of individuals or new marked individuals appearing in the population on the association analyses. Once individuals were assigned to social clusters, density maps were produced to assess whether different social clusters had different high-density areas.

Statistical analyses were run in Minitab 15.1. We used photo-identification data from 1986 to 2010 (see Baird et al. 2008) to assess whether social clusters identified in the association analyses showed particular preferences for different islands. A chi-square test was used to compare the observed versus expected number of sightings by cluster for each island. We used the percentage of sightings off each island to determine the expected number of sightings per island per cluster, given the number of sightings that contained individuals from each cluster. We used a logistic regression to compare environmental variables (depth, slope, distance from shore, and chl a concentrations) between low- and high-density cells, with low (0) and high (1) density as the response. To assess habitat differences between individuals of different social clusters, depth was calculated for all filtered locations using ArcGIS v. 9.2, with point location data layered on a bathymetric raster surface. We also generated depths from interpolated locations at 1-h intervals along the track lines to account for potential bias introduced by different duty cycling of tags. We used Mann-Whitney $U$-tests to compare water depth by social grouping, using the median water depth for each individual with only one of each pair or trio identified when data were not independent. We repeated this analysis separately with the filtered locations and interpolated locations to address any biases introduced by differences in duty cycling among individuals.

Information on feeding from encounters with Hawaiian insular false killer whales from 2000 to 2010 (see Baird et al. 2008) was also considered to assess whether feeding behavior occurs throughout the range of the population.

\section{RESULTS}

Twenty-nine satellite tags were deployed on 27 false killer whales from the Hawaiian insular population. No visible reactions to tagging were detected in 3 of the 29 tagging events. The most common immediate response to tagging was a fast dive (24 cases); in 3 of those cases the individual also exhibited a tail flick. In one case, an individual's tail slapped twice after tagging, and in another case a flinch (body shudder) was observed. This latter individual was holding a large wahoo Acanthocybium solandri in its mouth when tagged and did not drop the fish. There were 3 cases where single companion individuals also reacted with a fast dive. No prolonged reactions (e.g. initiation of high speed swimming away or multiple behaviors such as leaps or breaches) were observed, and tagged whales remained within the social groups they were in prior to tagging.

Two of the satellite tags failed to transmit, thus location data were obtained from 27 tags, deployed on 25 different individuals (Tables 1 \& 2). Of the 25 individuals, sex was known for 12 based on genetic analysis (9 males, 3 females), 3 were presumed to be females based on associations with neonates or small calves at some point during their sighting history (i.e. not at the time of tagging), 2 were presumed to be males based on long periods within the photographic database with no sightings of calves or neonates in proximity, and 8 were of unknown sex. Intervals over 
Table 2. Pseudorca crassidens. Details on duration of locations received and number of locations from satellite-tagged false killer whales. Span of days: total no. of days over which locations were obtained; No. days locations: no. of days with locations

\begin{tabular}{|c|c|c|c|c|c|c|}
\hline ID & Span of days & No. days locations & No. locations & No. locations $\mathrm{d}^{-1}$ & Cluster & Group number \\
\hline HIPc217 & 14 & 14 & 57 & 4.1 & 1 & $1^{\mathrm{b}}$ \\
\hline HIPc276 & 2 & 2 & 13 & 6.5 & 1 & 1 \\
\hline HIPc107 & 32 & 29 & 131 & 4.5 & 1 & 2 \\
\hline HIPc272 & 26 & 26 & 254 & 9.8 & 1 & 3 \\
\hline HIPc179 & 6 & 6 & 66 & 11.0 & 1 & 4 \\
\hline HIPc202 & 56 & 56 & 697 & 12.4 & 1 & $4^{\mathrm{b}}$ \\
\hline HIPc145 & 20 & 20 & 202 & 10.1 & 1 & 5 \\
\hline HIPc205 & 35 & 35 & 433 & 12.4 & 1 & 6 \\
\hline HIPc209 & 50 & 50 & 504 & 10.1 & 1 & 7 \\
\hline HIPc213 & 28 & 28 & 302 & 10.8 & 1 & 8 \\
\hline HIPc172 & 54 & 54 & 405 & 7.5 & 3 & 9 \\
\hline HIPc314 & 89 & 75 & 611 & 8.1 & 1 & 10 \\
\hline HIPc357 & 12 & 12 & 107 & 8.9 & - & 11 \\
\hline HIPc358 & 94 & 76 & 661 & 8.7 & 1 & $11^{\mathrm{b}}$ \\
\hline HIPc317 & 31 & 31 & 267 & 8.6 & 1 & 12 \\
\hline HIPc145 & 71 & 61 & 416 & 6.8 & 1 & 13 \\
\hline HIPc347 & 99 & 76 & 674 & 8.9 & With $3^{\mathrm{a}}$ & 14 \\
\hline HIPc365 & 16 & 16 & 133 & 8.3 & With 3 & 15 \\
\hline HIPc351 & 105 & 77 & 582 & 7.6 & 1 & 16 \\
\hline HIPc115 & 41 & 41 & 340 & 8.3 & 1 & 17 \\
\hline HIPc200 & 13 & 13 & 165 & 12.7 & 3 & 18 \\
\hline HIPc132 & 51 & 51 & 475 & 9.3 & 1 & 19 \\
\hline HIPc272 & 48 & 30 & 425 & 14.2 & 1 & 20 \\
\hline HIPc173 & 23 & 20 & 144 & 7.2 & 3 & 21 \\
\hline HIPc302 & 39 & 28 & 395 & 14.1 & 3 & $21^{\mathrm{b}}$ \\
\hline HIPc204 & 41 & 41 & 384 & 9.4 & 1 & 22 \\
\hline HIPc169 & 31 & 27 & 294 & 10.9 & 3 & 21 \\
\hline
\end{tabular}

which locations were obtained ranged from 2.1 to $104.8 \mathrm{~d}$ (median $=38.6 \mathrm{~d}$ ). Within that period actual locations were recorded from 2 to $77 \mathrm{~d}$ (median $=$ $30 \mathrm{~d})$ with tags duty cycled to transmit daily for only the first 50 or $60 \mathrm{~d}$ and at multiday intervals afterwards (Table 1). After filtering, 9137 locations were available, with a median number of locations per day of 8.9 (range $=4.1$ to $14.2, \mathrm{n}=27$ ). Although locations were available from 10 months of the year, $93.4 \%$ of all locations were obtained from the 7 mo period from July through January (Fig. 1). The range of the population, determined as a minimum convex polygon around all filtered locations, excluding land, was calculated as $82800 \mathrm{~km}^{2}$.

Twenty-six of 27 tagged whales had data temporally overlapping with one or more other individuals (Table 1). One individual whose tag transmitted for only 2.1 d (HIPc276, PcTag2) was excluded from further analyses. Assessment of distances between all the other possible pairs of individuals was undertaken, with 53 possible combinations. The mean dis-

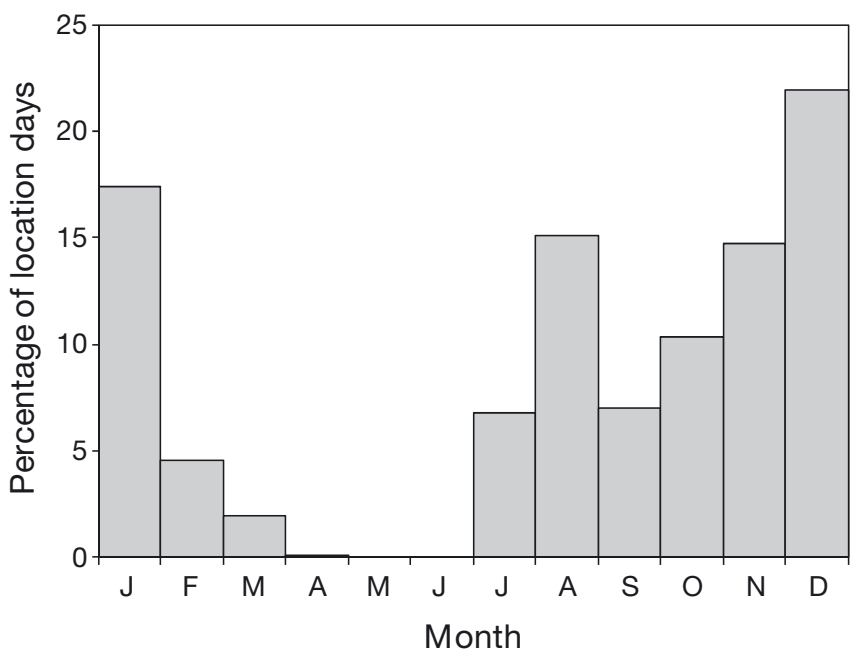

Fig. 1. Pseudorca crassidens. Seasonal distribution of tag data from Hawaiian insular false killer whales for the individuals representing the 22 groups in Table 2. Although data are available from 10 months of the year, the vast majority $(93.4 \%)$ were from July through January. Location days: days on which locations were obtained 
tance between individuals ranged from 2.0 to 249.2 $\mathrm{km}$ (grand mean $=80.0 \mathrm{~km}$ ). The maximum distance between individuals ranged from 9.9 to $502.1 \mathrm{~km}$ (grand mean $=188.4 \mathrm{~km}$ ). A plot of mean versus maximum distance apart (not shown) revealed a cluster of 6 combinations of individuals ( 5 pairs and 1 trio) with mean distances between them of $<5 \mathrm{~km}$, and maximum distances between individuals within these combinations of $<25 \mathrm{~km}$. Other pair combinations were widely dispersed, thus we chose these values as thresholds to distinguish whether individuals with temporally overlapping data were part of the same or different groups. One individual from each of these combinations (the one with the longest duration track) was used for analyses of habitat or spatial use, resulting in a sample size of 22 deployments (on 20 individuals), ranging from 13 to $104.8 \mathrm{~d}$ (median $=$ $40.5 \mathrm{~d}$ ), with a total of 8513 locations (Table 2).

Social network diagrams of all distinctive and very distinctive individuals (see Baird et al. 2008) documented either from March 2000 to August 2011 (Fig. 2) or from January 2007 to August 2011 (not shown) show 3 discrete clusters of individuals, with tag data available from 2 of the 3 clusters. Using maximum modularity to divide the study population

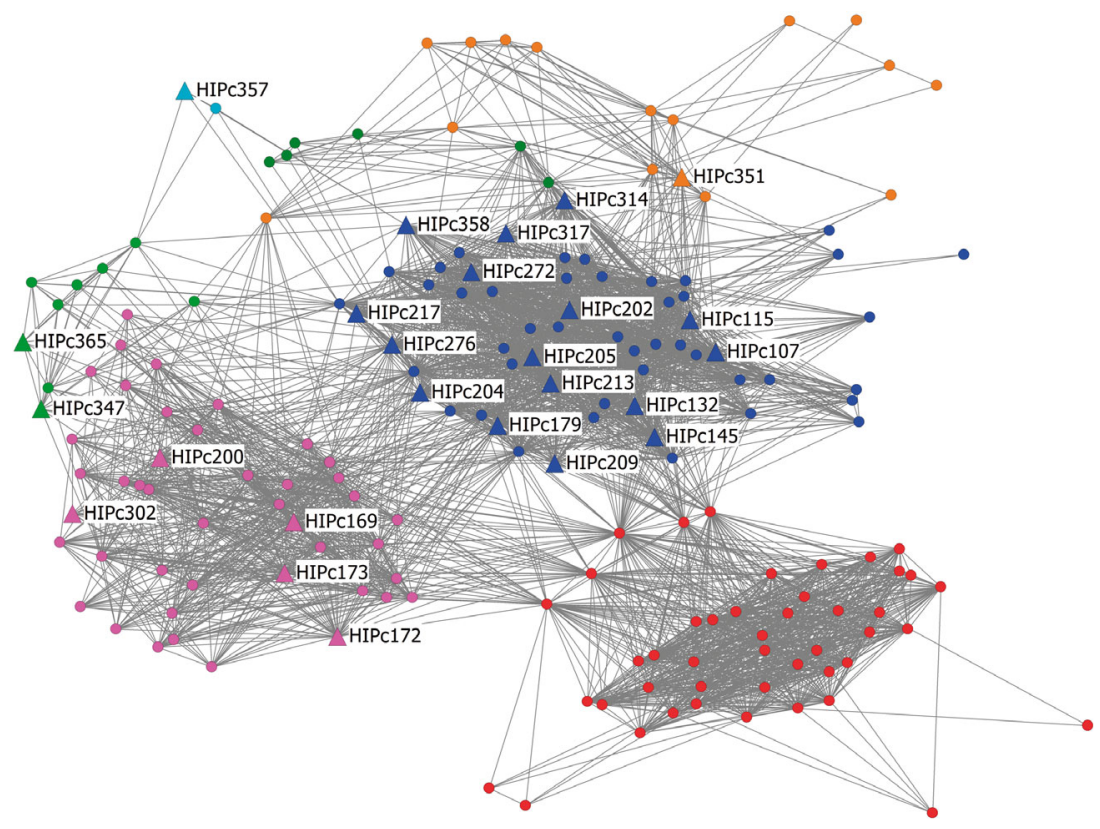

Fig. 2. Pseudorca crassidens. Social network diagram of distinctive and very distinctive Hawaiian insular false killer whales from photo-identification data available from 2000 through August 2011. The overall layout was determined using spring embedding with small changes to avoid overlap of nodes and labels. Cluster membership was determined using a network modularity technique and is indicated by color coding: Cluster 1 - blue; Cluster 2 - red; Cluster 3 - pink; other clusters are not named. Large triangles denote satellitetagged individuals (ID numbers are also shown) and assign individuals to clusters also supported division of the population (maximum modularity $=0.63$ ), producing 7 clusters. Three of these clusters correspond to the 3 obvious clusters visible in Fig. 2, although 4 tagged individuals were assigned to other smaller clusters. All 4 individuals were first documented in the study only in 2009, possibly as they acquired notches on the fin and became recognizable; thus, their positions peripheral to the main social clusters may be, at least in part, an artifact of the small sample size of observations for those individuals. Including only those individuals within Clusters 1 and 3 (Fig. 2) and excluding one of each pair or trio when individuals were not acting independently results in sample sizes of 16 (Cluster 1) and 3 (Cluster 3). For comparisons of depth by Cluster, 2 individuals closely associated with Cluster 3 (HIPc347 and HIPc365) were included. The median depth value for each individual was used in the analyses. A comparison of depth use indicated that individuals in Cluster 1 used significantly shallower depths (grand median $=608 \mathrm{~m}$ for actual locations versus $611 \mathrm{~m}$ for interpolated locations) than individuals in Cluster 3 (grand median $=1052 \mathrm{~m}$ for actual locations versus $1014 \mathrm{~m}$ for interpolated locations; Mann-Whitney $U$-test, $\mathrm{p}=0.023$ actual, $\mathrm{p}=0.012$ interpolated). Cluster 3, excluding HIP c347 and HIPc365, had the same grand median depth values; these remained significantly different from Cluster 1 depths when the interpolated locations were used (MannWhitney $U$-test, $\mathrm{p}=0.029$ ), but the difference was not significant $(\mathrm{p}=0.050)$ when the actual locations were used.

Using the photographic sighting history from 1986 to 2010, there were 98 sightings of photo-identified individuals from one or more of Clusters 1, 2 or 3, with sightings off O'ahu $(29.6 \%)$, Maui $(21.4 \%)$ and Hawai'i $(49.0 \%)$. Individuals from Cluster 1 were seen on 73 occasions, whereas individuals from Cluster 2 (17 occasions) and Cluster 3 (20 occasions) were documented less often. We used the percentage of sightings off each island (above) to determine the expected number of sightings per island per cluster, given the number of sightings of individuals from each cluster. A comparison of observed versus expected number of sightings by cluster 
for each island indicated that Cluster 2 individuals were seen more often than expected off the island of Hawai'i, and less frequently than expected off $\mathrm{O}^{\prime} \mathrm{ahu}$ or Maui (chi-square goodness of fit, $\mathrm{df}=2$, chi-square $=7.827, \mathrm{p}=0.020$ ), whereas sightings of Cluster 1 and Cluster 3 individuals by island did not differ from expected frequencies.

Two whales (HIPc145 and HIPc272, both from Cluster 1) were tagged on 2 occasions each, once off the island of Hawai'i and once off the island of $\mathrm{O}^{\prime} \mathrm{ahu}$ (Table 1). Plots of spatial use for the individuals each time they were tagged revealed a number of differences (Fig. 3). In 2008, individual HIPc145 was only documented off the north end of the island of Hawai'i, whereas in 2009 this animal was documented from Ni'ihau to the island of Hawai'i. In 2008, HIPc272 was documented from Hawai'i Island to O'ahu but primarily used the leeward (west and south) sides of the islands, whereas in 2010, HIPc272 remained in the area from O'ahu to Maui and made extensive use of both windward and leeward sides of the islands (Fig. 3).

Using cells where the density is $\geq 2$ SD above the mean to indicate high-density areas, density plots using the 4 different measures showed generally similar patterns of spatial use (Figs. 4 \& 5), with highuse areas occurring off the north side of the island of Hawai'i (both east and west sides), in a broad area extending from north of Maui to northwest of Moloka'i, and in a small area to the southwest of Lana'i. Considering all values above the mean density, the broad high-density area north of Maui and Moloka'i did link with the high-density area to the southwest of Lana'i in a broader area that also encompasses much of the island of $\mathrm{O}^{\prime}$ ahu and Penguin Bank west of Moloka'i (Fig. 5).

The range in possible values associated with each method differed, as did the variation. The number of unique tags documented in any cell where false killer whales were recorded ranged from 1 to 17
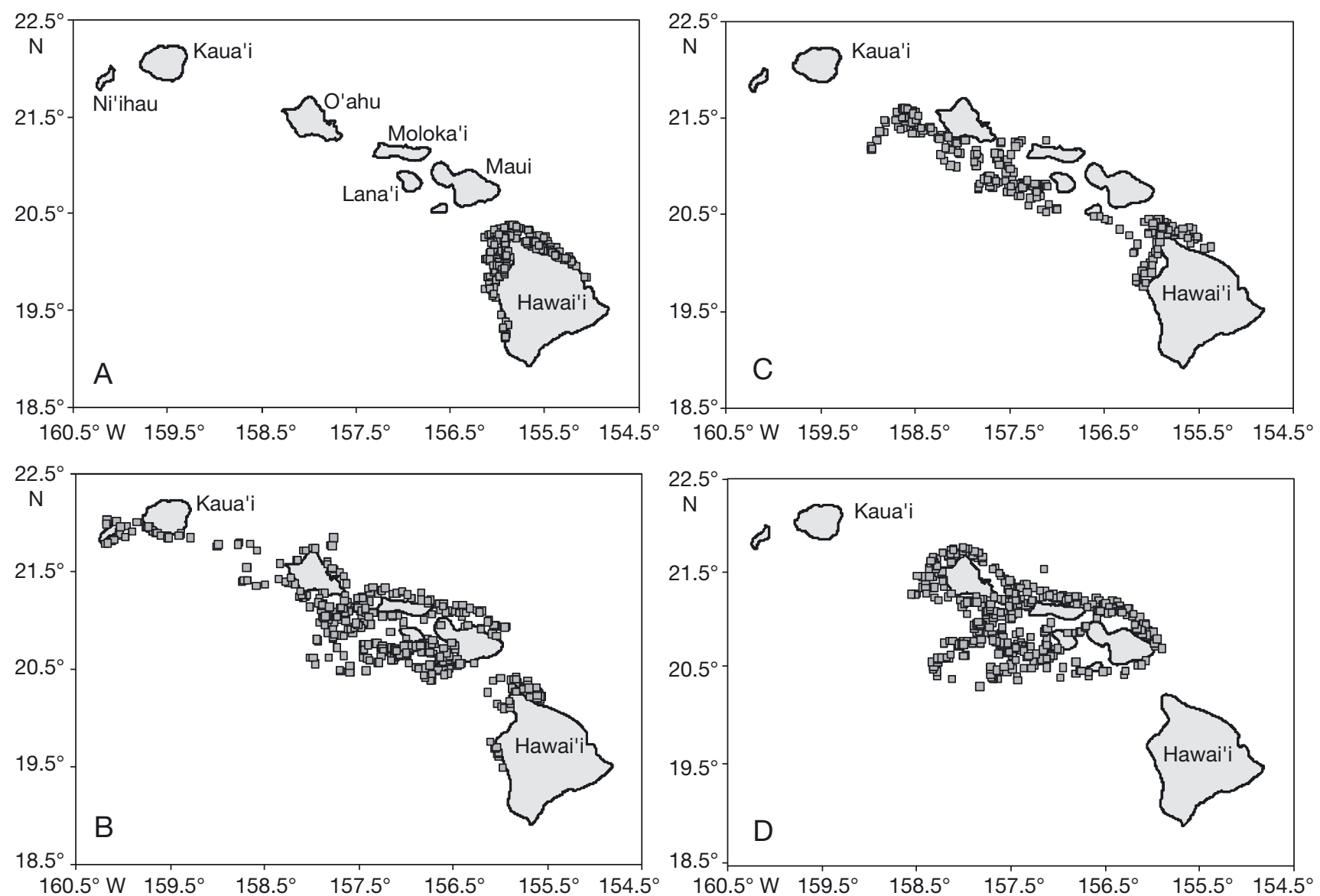

Fig. 3. Pseudorca crassidens. Spatial use patterns of 2 individual Hawaiian insular false killer whales (both from Cluster 1), each tagged on 2 separate occasions. Left: HIPc145 tagged (A) off Hawai'i in 2008 (16 July-5 August) and (B) off O'ahu in 2009 (17 October-27 December). Right: HIPc272 tagged (C) off Hawai'i in 2008 (4-30 September) and (D) off O’ahu in 2010 (22 October-9 December) 

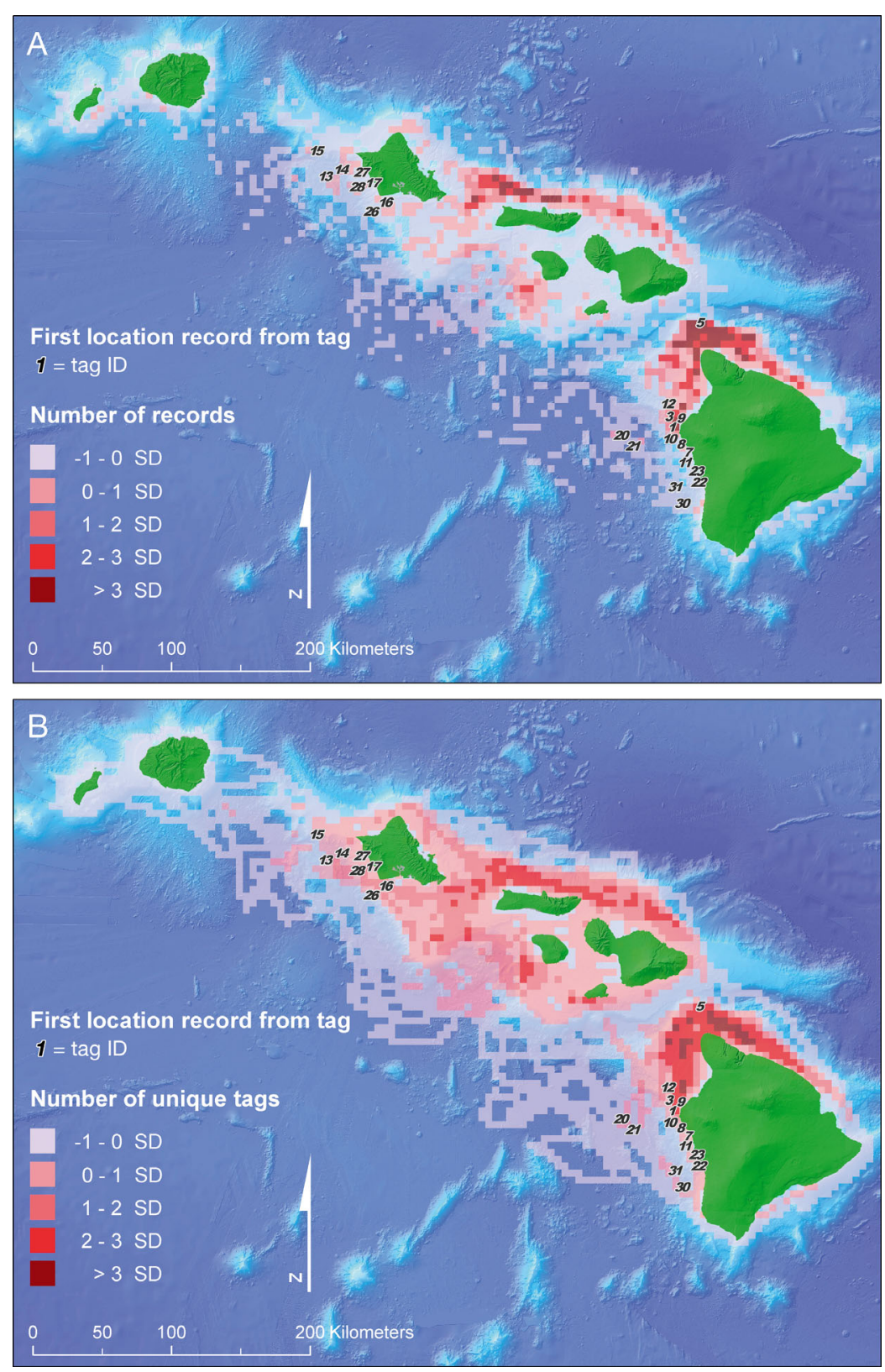

Fig. 4. Pseudorca crassidens. Density map of Hawaiian insular false killer whales based on (A) the number of records (locations) and (B) the number of unique tags

(mean $=4.12, \mathrm{SD}=3.37)$, whereas the total visit duration (number of hours) per cell ranged from $<1.0$ to 159.63 (mean $=9.74, \mathrm{SD}=16.96)$. The density plot based on the number of records had the least number of cells with records (Fig. 4); as noted in 'Materials and methods', this approach under-represents the range used in areas that are used less frequently because of the duty cycling of the tags (Table 2). This method, along with the approach using the number of unique tags and the total visit duration, all showed a high-density area off the west side of the island of Hawai'i immediately to the north of the principal tag deployment location. This high-density area varied in size depending on the method used -4 cells (number of records), 7 cells (total visit duration) or $>9$ cells (number of unique tags) resulting in the high-density area merging with the larger high-density area off the north end of the island. In all 3 cases this high-density area was likely an artifact of its proximity to the location where the majority of tags were deployed (13 of 22 groups used). Using average speed for each individual and the distance to the farthest vertex of the convex polygon, the time periods after tagging for excluding locations (for the late start analyses) ranged from 2.11 to $4.28 \mathrm{~d}$ (median $=$ $3.21 \mathrm{~d}$ ). When total visit duration taking into account a late start was used, there were only 2 high-density cells in this area (Fig. 5), suggesting that this method was least biased in terms of initial tagging location; therefore, this method was used in further analyses.

Using total visit duration with a late start summed over all 22 deployments, individuals spent slightly more time on the windward sides of the islands $(52.2 \%)$ than the leeward sides $(47.8 \%)$. However, there were more populated cells on the leeward side than on the windward side of the islands (1668 of the total of 2360 populated cells; $71.1 \%$ ), although it should be noted that many of the cells classified as leeward are actually outside of the lee created by the islands. The majority of high-density cells were on the windward sides of the islands (89 of the total of 114 high-density cells; 79.1\%). Combined, these reflect that animals ranged broadly on the leeward sides of the islands, but there were few specific cells that were of particularly high density on the leeward side. As environmental variables such as depth and distance from shore may be correlated, a logistic regression was used to compare depth, distance from shore, slope, and chl a concentration for high- and low-density cells. The logistic regression showed significant differences in depth (high- 

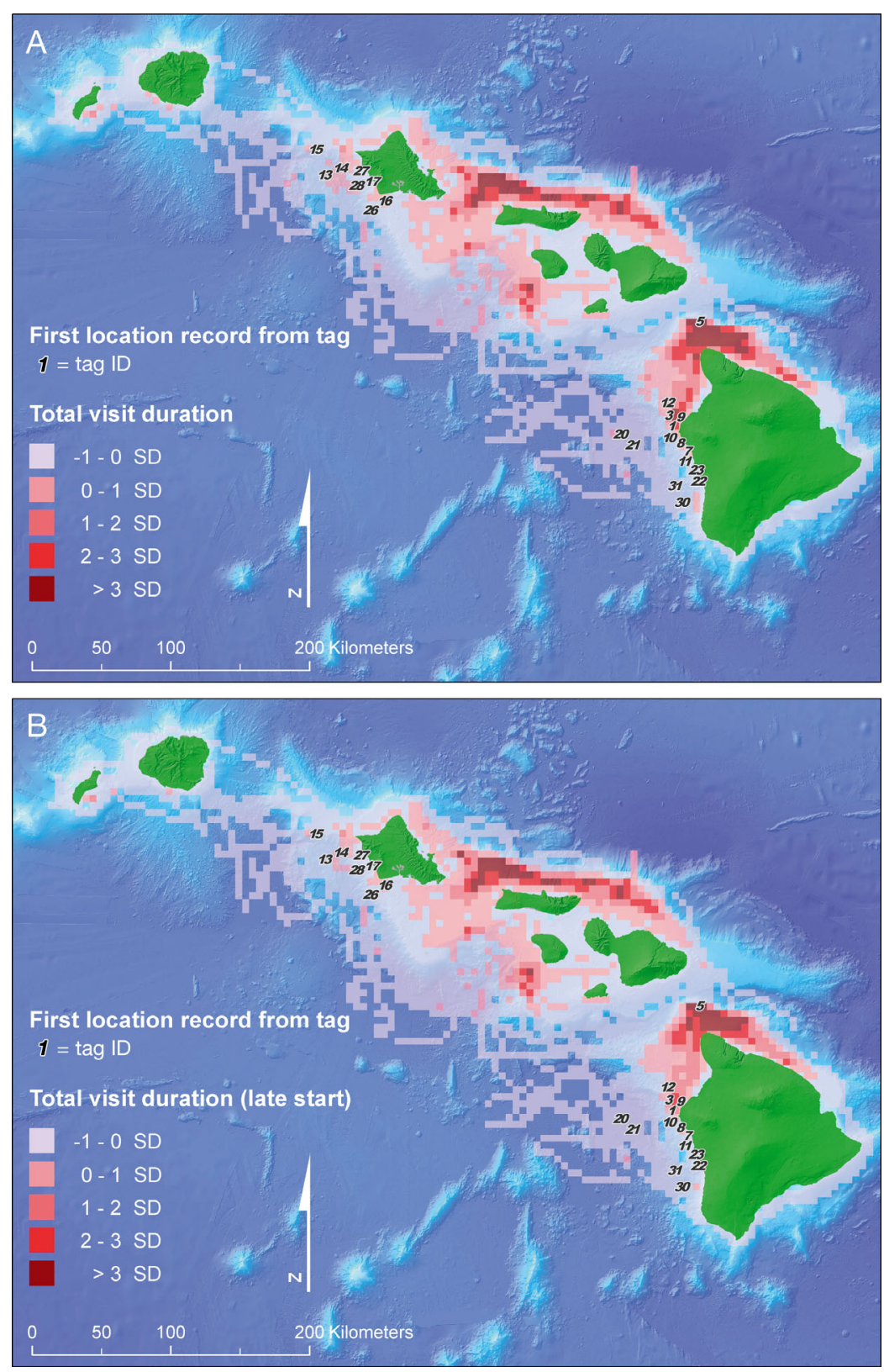

Fig. 5. Pseudorca crassidens. Density maps of Hawaiian insular false killer whales based on (A) total visit duration and (B) total visit duration with a late start (see 'Materials and methods' for explanation) sity cells was fairly narrow and strongly peaked (with the modal depths from 500 to $800 \mathrm{~m}$ ), whereas the distribution of depths of low-density cells was relatively uniform with no clear peak (Fig. 6).

Density plots showed that individuals from Clusters 1 and 3 had similar overall ranges but different highdensity areas, with individuals from Cluster 1 using all 3 of the highdensity areas (north and northwest of Moloka'i, southwest of Lana' $i$, and the north end of Hawai'i Island), whereas individuals from Cluster 3 primarily used the area from north of Maui to northwest of Moloka'i (Fig. 7).

We have information from 26 encounters with Hawaiian insular false killer whales between 2000 and 2010 where information on predation (or lack of predation) was recorded, with encounters off $\mathrm{O}^{\prime}$ ahu $(\mathrm{n}=7)$, Maui $(\mathrm{n}=1)$, and Hawai'i $(\mathrm{n}=18)$, all in lowdensity areas. Predation on fish was documented in 6 of 7 encounters off O'ahu, 1 of 1 encounter off Maui, and 15 of 18 encounters off Hawai'i ( 2 of the 3 encounters with no predation off the island of Hawai'i were among the shortest encounters, both less than $2 \mathrm{~h}$ in duration).

\section{DISCUSSION}

Location data from satellite tags indicate that the range of the Hawaiian insular population of false killer whales encompasses an area of at least $82800 \mathrm{~km}^{2}$, including the waters from the west side of the island of $\mathrm{Ni}^{\prime}$ ihau to the east side of the island density median $=623 \mathrm{~m}$, low-density median $=1679 \mathrm{~m}$; $\mathrm{p}<0.001$ ), slope (high-density median $=3$, low-density median $=6 ; \mathrm{p}=0.001$ ), and $\mathrm{chl} a$ concentration (high-density median $=0.082 \mathrm{mg} \mathrm{m}^{-3}$, low-density median $=0.074 \mathrm{mg} \mathrm{m}^{-3} ; \mathrm{p}=0.001$ ). Although distance from shore differed between high- and low-density cells (high-density median $=10.8 \mathrm{~km}$, low-density median $=18.9 \mathrm{~km}$ ), this was not a significant predictor in the regression when depth was also included in the model. The distribution of depths for high-denof Hawai'i, and occasionally offshore as far as 122 $\mathrm{km}$. Whether this also represents the historical range of the population is unknown. There is evidence that the population has undergone a decline in abundance (Baird 2009, Reeves et al. 2009, Oleson et al. 2010), and the ranges of some odontocete populations are known to contract as abundance decreases (Rugh et al. 2010), suggesting that the historical range may have been larger than is currently known. 


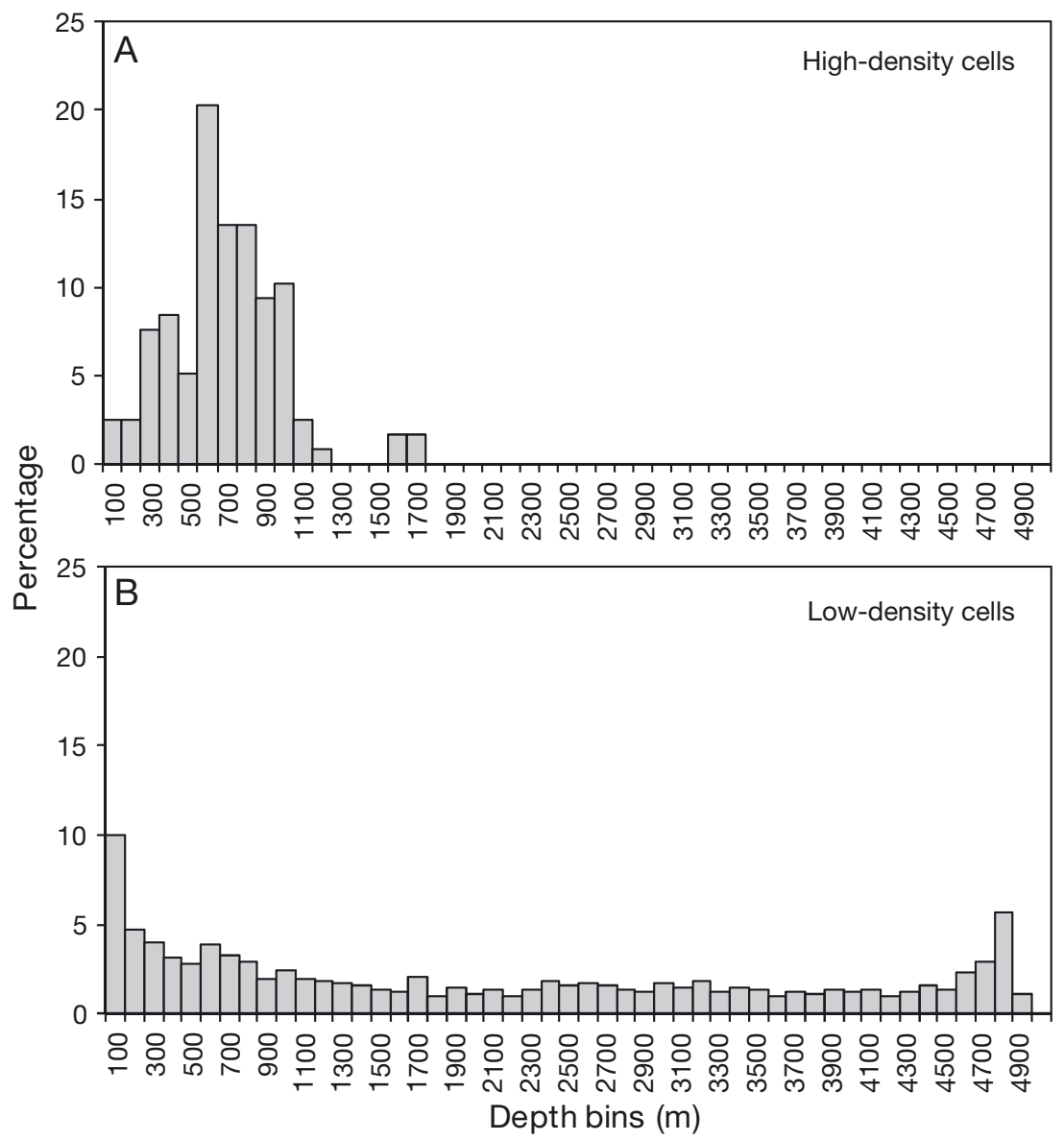

Fig. 6. Pseudorca crassidens. Comparison of depth (percent occurrence in each depth bin) of (A) high-density cells and (B) low-density cells

only deployed satellite tags on individuals from 2 of the 3 main social clusters (Fig. 2) suggest that the range of the population may be underestimated, and that there may be other highdensity areas than those identified to date. From satellite data, individuals from Clusters 1 and 3 have been documented from east of Hawai'i Island to west of O'ahu, whereas animals from Cluster 1 (albeit with a much larger sample size) have also been documented extending west to the western side of Ni'ihau. Based on photo-identification data, individuals in Cluster 2 are known to occur as far west as O'ahu. However, unlike individuals from Clusters 1 and 3, the vast majority of sightings of Cluster 2 individuals have been off the island of Hawai'i, and they are documented there significantly more often than would be expected given the geographic distribution of encounters with photoidentification data. This social grouping is documented off the island of Hawai'i more frequently than expected, but individuals from the group are seen less frequently than individuals in Clusters 1 or 3, implying that their ranges may differ somewhat.

We also identified several areas that appear to be high-use areas for the population. How robust is our assessment of the range and of high-density areas for the population? Although our sample size is large (22 'groups' spanning an average of $40 \mathrm{~d}$ each), there are several limitations that suggest the range of the population is likely underestimated, and there are probably other high-use areas that have not been identified by our sample of tagging data. The limitations of our data set include a strong seasonal bias (Fig. 1), with virtually no information available on spatial use during 4 months of the year, from March through June. From sightings data, both from prior to the initiation of our satellite tagging work and from colleagues working in the islands (Baird et al. 2008), we know Hawaiian insular false killer whales do use some of the same areas documented by satellite data during the months of March through June; however, it is not known whether other areas outside of the records from our satellite tags are also used.

Probably more importantly, the presence of social clustering within the population and the fact that we
Information on movements of individuals from Cluster 2 is needed to assess whether their range or highdensity areas vary from those of individuals from Clusters 1 or 3 . In addition, data from Cluster 3 individuals are more restricted seasonally than data from Cluster 1 individuals, and additional deployments on Cluster 3 individuals outside of the October through January period are needed.

Density analyses using a variety of approaches indicate that usage of the populations' overall range is not uniform (Figs. 4 \& 5); in particular, there are several areas that appear to have much higher usage than others. We suggest that the measure of density taking into account the total visit duration, but with a 'late start' to discount data immediately after tagging (to account for biases in movement patterns based on location of tagging), is probably the best of the 4 used. When we chose grid cells that were $\geq 2 \mathrm{SD}$ above the mean value as those indicating particularly high use, we found 2 large high-use areas (one approximately $900 \mathrm{~km}^{2}$ and the other approximately $1350 \mathrm{~km}^{2}$ ), as well as 4 small high-use areas. Of the 4 

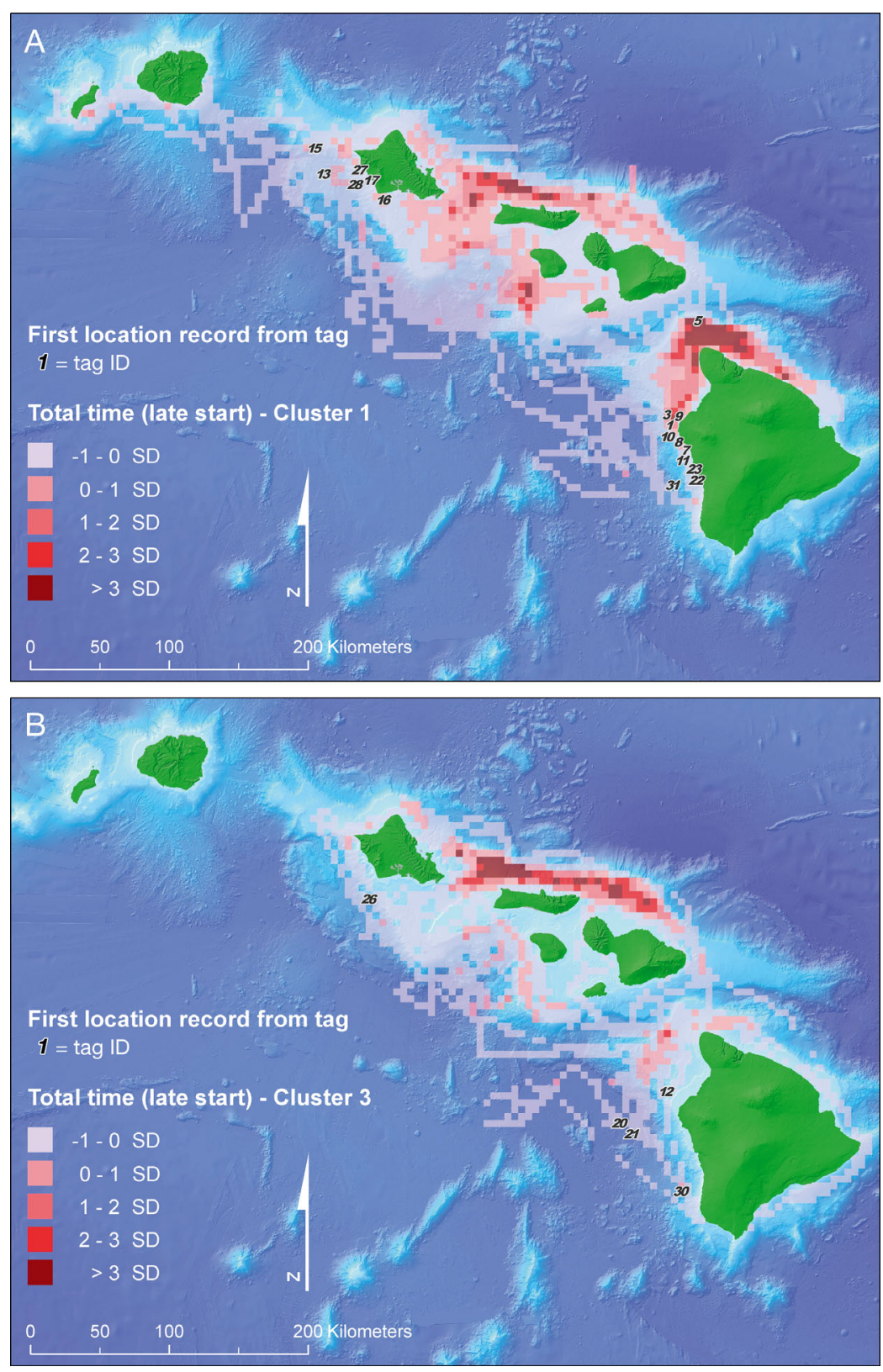

Fig. 7. Pseudorca crassidens. Density maps of Hawaiian insular false killer whales based on total visit duration with a 'late start' of (A) individuals from Cluster 1 and (B) individuals from Cluster 3 (see Fig. 2)

small areas, 3 were represented by a single grid cell $\left(25 \mathrm{~km}^{2}\right)$, whereas the fourth was a larger area (approximately $125 \mathrm{~km}^{2}$ ) located to the southwest of the island of Lana'i. The 2 large areas included an area off the north end of the island of Hawai'i encompassing both windward and leeward sides of the island, and a broad area ranging from east of $\mathrm{O}^{\prime} \mathrm{ahu}$ to north of Maui located entirely off the windward side of the islands (Fig. 5). Assessment of density by social clusters indicated that the area off the north end of Hawai'i Island was only a highdensity area for individuals from Cluster 1 (Fig. 7). Conversely, the area off the north side of Moloka'i was the primary high-density area for individuals from Cluster 3, although individuals from Cluster 1 also appeared to commonly use this area. Such overlap in range but differences in high-density areas is similar to what has been reported for 'pods' of fish-eating killer whales Orcinus orca from the coastal waters of Washington and British Columbia (Hauser et al. 2007). The differences in high density areas for Clusters 1 and 3 suggest that highdensity areas for Cluster 2 are likely not reflected in this analysis.

It is interesting to note that most of the high-density areas are on the windward, rather than on the leeward side of the islands (Fig. 6), even though on average individuals spent approximately the same amount of time on the leeward sides of the islands. The current analyses indicate that individuals appear to extend their range farther offshore on the leeward sides and generally use deeper waters, albeit with fewer areas of concentration. Higher density areas were on average shallower (Fig. 6), closer to shore, and with gentler slopes than lower density areas. Higher density areas also had higher average surface chl a concentrations (approximately $10 \%$ higher) than lower density areas. Such higher levels are likely indicative of different oceanographic processes in these areas that enhance productivity. The North Hawaiian Ridge Current runs along the north side of the islands in a northwesterly direction (Qiu et al. 1997), and intersects with both of the large high-density areas, possibly contributing to localized upwelling that may increase productivity. However, in Hawai'i, a large amount of chlorophyll is subsurface (Ondrusek et al. 2001) and would not be detected using the remote methods available for the present study.

Designation of critical habitat under the ESA requires listing PCEs, which could include feeding and breeding areas. Based on genetic analysis 
(Chivers et al. 2007, 2010), long-term photo-identification data (Baird et al. 2008), and our results, this population is resident to the area around the main Hawaiian Islands year-round. Satellite tracking data suggest that individuals can, and sometimes do, move throughout most of the entire range of the population rapidly and semi-regularly (Baird et al. 2010, present study) and, unlike baleen whales, there is likely no specific breeding area within the range of this population.

The available evidence suggests that false killer whales feed throughout their range, as foraging and feeding behavior has been documented in virtually all of the long (e.g. $>2$ h) encounters that we have had with this population. All of our encounters have been in areas that, based on our analyses, are actually relatively low-density areas for this population; thus, we cannot directly assess feeding within highdensity areas. Like other delphinids, false killer whales probably feed virtually daily year-round. False killer whales in Hawai'i have been documented feeding on a wide variety of large game fish, including wahoo, mahi mahi Coryphaena hippurus, yellowfin tuna Thunnus albacares, albacore tuna $T$. alalunga, skipjack tuna Katsuwonus pelamis, broadbill swordfish Xiphias gladius, and threadfin jack Alectis ciliaris, among others (Baird et al. 2008, Baird 2009). Most of the prey species are generally considered to be broadly ranging, widely migratory species, but little is known of their specific distribution within Hawaiian waters (Oleson et al. 2010), so it is difficult to specify subsets of areas within their range that may be particularly important foraging areas. Although some of the known prey species vary in abundance around the main Hawaiian Islands seasonally, most species are found around the islands year-round (Oleson et al. 2010). Without a quantitative assessment of diet for false killer whales, it is not possible to determine whether seasonal variation in fish abundance would influence false killer whale spatial use. Dive data from the Mk10-A satellite tags are available from 4 individuals, 3 from Cluster 3 and 1 from Cluster 1, although the dive records are not continuous over the entire period of tag attachments. Data from these tags include dive depths and durations. Although the dive data set has not yet been analyzed, our existing sample from just 4 individuals is likely insufficient to assess whether behavior in the high-density areas differs from other areas within the range of the population. False killer whales in Hawai'i feed extensively on fish found primarily at the surface (Baird et al. 2008, Baird 2009), but also bring prey up from depth, so whether information on depths and durations of dives can be used to assess which areas are more or less important for foraging is not yet known. Without such information, it may be appropriate to use the locations where the animals spend most of their time as a proxy for feeding areas (Bailey \& Thompson 2006). Given the amount of time the whales spent in the high-density areas, and the frequency at which false killer whales are observed feeding during encounters, we suspect that those areas likely represent particularly important feeding areas.

For cetaceans listed under the ESA, critical habitat has been designated for North Atlantic right whales Eubalaena glacialis (in 1994), 'southern resident' killer whales (in 2006), North Pacific right whales E. japonica (in 2006 and 2008), and Cook Inlet beluga whales Delphinapterus leucas (in 2011). Designation of critical habitat for each of these species has differed in terms of the spatial extent of coverage relative to the known range of the species, and has generally not relied on published peer-reviewed evaluation of specific and essential habitat features. For example, for southern resident killer whales, a population that uses both US and Canadian waters, the critical habitat designation was restricted to US waters in the Strait of Juan de Fuca, around the San Juan Islands, and in Puget Sound (Federal Register 2006) based on the use of opportunistic sightings, albeit a substantial number of them. However, the population spends most of the winter and spring months outside of these areas, and could be subject to unknown risk factors during these periods, but a paucity of sightings and other detection data precluded NMFS from designating critical habitat in other areas. North Pacific right whales are known to range from Hawai'i and California to the Bering Sea, but primarily inhabit shelf and open-ocean waters off Alaska. Two areas that surround most of the sightings of this species in the last $30 \mathrm{yr}$ were designated as critical habitat, both in Alaskan waters, but these areas are separated by almost 500 km (Federal Register 2008). The present study represents a quantitative assessment of important habitat areas that are commonly used by Hawaiian insular false killer whales. Although other factors must be considered in any critical habitat designation under the ESA, this study provides scientific information that may allow for the initial assessment of PCEs.

Acknowledgements. Fieldwork was primarily funded by grants and contracts to Cascadia Research Collective from the National Marine Fisheries Service Pacific Islands Fisheries Science Center and the US Navy (N45) through the 
Southwest Fisheries Science Center, Woods Hole Oceanographic Institution, and the Naval Postgraduate School. The Wild Whale Research Foundation and Dolphin Quest provided additional support. We thank individuals who contributed to the long-term photo-identification data set, particularly Dan Salden, Mark Deakos, and Tori Cullins, as well as Susan Chivers and the Southwest Fisheries Science Center for sex determinations from biopsy samples, and Megan Ferguson for developing a program to measure distances among pairs of individuals. We thank Megan Ferguson, Jean Higgins, Sam Pooley and an anonymous reviewer for their helpful comments on the manuscript. Improvements to the tagging methods were funded by Office of Naval Research Grant N000140811203. Chlorophyll a data were made available through NOAA's CoastWatch Program and NASA's Goddard Space Flight Center OceanColor Web. Tagging was undertaken under NMFS Scientific Research Permits No. 731-1774, 7741714, and 14097.

\section{LITERATURE CITED}

Acevedo-Gutiérrez A, Brennan B, Rodriguez P, Thomas M (1997) Resightings and behavior of false killer whales (Pseudorca crassidens) in Costa Rica. Mar Mamm Sci 13: 307-314

> Andrews RD, Pitman RL, Balance LT (2008) Satellite tracking reveals distinct movement patterns for Type B and Type C killer whales in the southern Ross Sea, Antarctica. Polar Biol 31:1461-1468

Bailey H, Thompson P (2006) Quantitative analysis of bottlenose dolphin movement patterns and their relationship with foraging. J Anim Ecol 75:456-465

Baird RW (2009) A review of false killer whales in Hawaiian waters: biology, status, and risk factors. Report prepared for the US Marine Mammal Commission under Order No. E40475499. Marine Mammal Commission, Silver Spring, MD. Available at www.cascadiaresearch.org/ hawaii/publications.htm

Baird RW, Gorgone AM, McSweeney DJ, Webster DL and others (2008) False killer whales (Pseudorca crassidens) around the main Hawaiian Islands: long-term site fidelity, inter-island movements, and association patterns. Mar Mamm Sci 24:591-612

Baird RW, Schorr GS, Webster DL, McSweeney DJ, Hanson MB, Andrews RD (2010) Movements and habitat use of satellite-tagged false killer whales around the main Hawaiian Islands. Endang Species Res 10:107-121

Baird RW, Schorr GS, Webster DL, McSweeney DJ, Hanson MB, Andrews RD (2011a) Movements and spatial use of false killer whales in Hawai'i: satellite tagging studies in 2009. Report prepared under Order No. AB133F09SE 4132 from the Pacific Islands Fisheries Science Center, Honolulu, HI. http://www.cascadiaresearch.org/hawaii/ publications.htm

Baird RW, Schorr GS, Webster DL, McSweeney DJ, Hanson MB, Andrews RD (2011b) Movements of two satellite- tagged pygmy killer whales (Feresa attenuata) off the island of Hawai'i. Mar Mamm Sci 27:E332-E337

Chivers SJ, Baird RW, McSweeney DJ, Webster DL, Hedrick NM, Salinas JC (2007) Genetic variation and evidence for population structure in eastern North Pacific false killer whales (Pseudorca crassidens). Can J Zool 85: 783-794

Chivers SJ, Baird RW, Martien KM, Taylor BL and others (2010) Evidence of genetic differentiation for Hawai'i insular false killer whales (Pseudorca crassidens). NOAA Tech Memo NMFS-SWFSC-458

Federal Register (2006) Designation of critical habitat for southern resident killer whale. Federal Register 71: $69054-69070$

Federal Register (2008) Designation of critical habitat for the North Pacific right whale. Federal Register 73: 19000-19014

Federal Register (2010) Proposed Endangered status for the Hawaiian insular false killer whale distinct population segment. Federal Register 75:70169-70187

Hauser DDW, Logsdon MG, Holmes EE, VanBlaricom GR, Osborne RW (2007) Summer distribution patterns of southern resident killer whales Orcinus orca: core areas and spatial segregation of social groups. Mar Ecol Prog Ser 351:301-310

Newman MEJ (2004) Analysis of weighted networks. Phys Rev E Stat Nonlin Soft Matter Phys 70:056131

Newman MEJ (2006) Modularity and community structure in networks. Proc Natl Acad Sci USA 103:8577-8582

Oleson EM, Boggs CH, Forney KA, Hanson MB and others (2010) Status review of Hawaiian insular false killer whales (Pseudorca crassidens) under the Endangered Species Act. NOAA Tech Memo NMFS-PIFSC-22

Ondrusek ME, Bidigare RR, Waters K, Karl DM (2001) A predictive model for estimating rates of primary production in the subtropical North Pacific Ocean. Deep-Sea Res Part II 48:1837-1863

> Qiu B, Koh DA, Lumpkin C, Flament P (1997) Existence and formation mechanism of the North Hawaiian Ridge Current. J Phys Oceanogr 27:431-444

Reeves RR, Leatherwood S, Baird RW (2009) Evidence of a possible decline since 1989 in false killer whales (Pseudorca crassidens) around the main Hawaiian Islands. Pac Sci 63:253-261

> Rugh DJ, Shelden KEW, Hobbs RC (2010) Range contraction in a beluga whale population. Endang Species Res 12: $69-75$

> Schorr GS, Baird RW, Hanson MB, Webster DL, McSweeney DJ, Andrews RD (2009) Movements of satellite-tagged Blainville's beaked whales off the island of Hawai'i. Endang Species Res 10:203-213

Whitehead H (2008) Analyzing animal societies: quantitative methods for vertebrate social analysis. University of Chicago Press, Chicago, IL

Woodworth PA, Schorr GS, Baird RW, Webster DL and others (2011) Eddies as offshore foraging grounds for melonheaded whales (Peponocephala electra). Mar Mamm Sci doi:10.1111/j.1748-7692.2011.00509.x

Submitted: October 17, 2011; Accepted: April 17, 2012

Proofs received from author(s): July 9, 2012
Editorial responsibility: Ana Cañadas,

Madrid, Spain 